\title{
Antimutagenic and antirecombinagenic activities of noni fruit juice in somatic cells of Drosophila melanogaster
}

\author{
LEONARDO P. FRANCHI ${ }^{1}$, NILZA N. GUIMARÃES ${ }^{1}$, LAISE R. DE ANDRADE ${ }^{1}$, \\ HELOÍSA H.R. DE ANDRADE ${ }^{2}$, MAURÍCIO LEHMANN ${ }^{3}$, RAFAEL R. DIHL ${ }^{3}$ and KÊNYA S. CUNHA ${ }^{1}$ \\ ${ }^{1}$ Laboratório de Genética Toxicológica, Departamento de Bioquímica e Biologia Molecular, ICB, \\ Universidade Federal de Goiás/UFG, Campus II, Samambaia, Km 13, Caixa Postal 131, 74001-970 Goiânia, GO, Brasil \\ ${ }^{2}$ Laboratório de Estomatologia, Hospital das Clínicas de Porto Alegre, \\ Universidade Federal do Rio Grande do Sul/UFRGS, Rua Ramiro Barcelos, 2350, 90035-903 Porto Alegre, RS, Brasil \\ ${ }^{3}$ Laboratório da Toxicidade Genética, Universidade Luterana do Brasil/ULBRA, \\ Av. Farroupilha, 8001, Prédio 22, $4^{\circ}$ andar, TOXIGEN, sala 29, 92425-900 Canoas, RS, Brasil
}

Manuscript received on October 10, 2011; accepted for publication on December 5, 2011

\begin{abstract}
Noni, a Hawaiian name for the fruit of Morinda citrifolia L., is a traditional medicinal plant from Polynesia widely used for the treatment of many diseases including arthritis, diabetes, asthma, hypertension and cancer. Here, a commercial noni juice (TNJ) was evaluated for its protective activities against the lesions induced by mitomycin C (MMC) and doxorrubicin (DXR) using the Somatic Mutation and Recombination Test (SMART) in Drosophila melanogaster. Three-day-old larvae, trans-heterozygous for two genetic markers ( $m w h$ and $f r^{3}$ ), were co-treated with TNJ plus MMC or DXR. We have observed a reduction in genotoxic effects of MMC and DXR caused by the juice. TNJ provoked a marked decrease in all kinds of MMC- and DXR-induced mutant spots, mainly due to its antirecombinagenic activity. The TNJ protective effects were concentration-dependent, indicating a dose-response correlation, that can be attributed to a powerful antioxidant and/or free radical scavenger ability of TNJ.
\end{abstract}

Key words: antigenotoxicity, doxorrubicin, mitomycin C, SMART, noni juice.

\section{INTRODUCTION}

Morinda citrifolia L. (Rubiaceae) - popularly known in Hawaii and Brazil as noni, is also called "indian mulberry", "ba ji tian", "nono", “nonu”, "cheese fruit", and "nhau". It is one of the most traditional and popular medicinal plants in Polynesia, and its use has been recorded for over 2000 years (Earle 2001). Noni is native to Southeastern Asia (Indonesia) and Australia, this small evergreen tree

Correspondence to: Kênya Silva Cunha

E-mail:kenya@icb.ufg.br or shrub is noted for its extremely wide range of environmental tolerances and now has a pantropical distribution, found even at Central and South America (from Mexico to Panama, Venezuela and Surinam) (Nelson 2006). All parts of the plant, especially the fruit, have been utilized as a food source or for its medicinal properties (Cardon 2003, Wang et al. 2002). As a medicinal plant, noni has been used to prevent and cure several diseases. Its therapeutic effects include antimicrobial, analgesic, hypotensive, anti-inflammatory, anticancer and 
immunological system stimulation effects (ChanBlanco et al. 2006, Wang et al. 2002, Yu et al. 2008). Currently, the use of Morinda citrifolia has become widespread, and its products are commercially available in health food stores, chain grocery stores specializing in natural foods, and on the internet. Both leaves and fruits are processed and sold as capsules, tea, and juice forms, although the fruit juice is the predominant formulation.

The anti-inflammatory, analgesic, hypotensive and cardiovascular activities of Morinda citrifolia were reviewed in Chan-Blanco et al. (2006). Antimicrobial effects of ethanol and hexane extracts of noni have been described, including their antitubercular activity, with the extracts inhibiting the growth of Mycobacterium tuberculosis by $89-95 \%$ (Saludes et al. 2002). Immunomodulatory effects were demonstrated for commercially available juice (Tahitian Noni ${ }^{\mathbb{B}}$ Juice - TNJ); polysaccharide-rich substance from noni juice (noni-ppt) and fruit juice concentrates, both in vivo and in vitro (Hirazumi and Furusawa 1999, Hirazumi et al. 1996, Palu et al. 2008), and recently Harada et al. (2009) detected neuroprotective effect of noni juice against the development of ischemic neuronal damage in mice.

Furthermore, noni-ppt showed antitumor activity in the Lewis lung peritoneal carcinomatosis model (Hirazumi and Furusawa 1999) and prophylactic and therapeutic potential against the immunomodulatorsensitive sarcoma 180 tumor system (Furusawa et al. 2003). The anticarcinogenic properties of the TNJ have been observed at the initiation stage of chemical carcinogenesis, by preventing the carcinogen-DNA adduct formation and/or by acting as an antioxidant (Wang and $\mathrm{Su} 2001$ ).

Over 150 phytochemical compounds have already been identified in the noni plant (for a review see Chan-Blanco et al. 2006), and the major micronutrients are phenolic compounds, organic acids and alkaloids. The fruit is described to have flavonoids, lignans and coumarins (Potterat and Hamburger 2007). Although antraquinones occur nearly exclusively in the roots (Deng et al. 2007, Ohsawa and Ohba 1993), a potent quinone reductase (QR) inducer, 2-methoxy-1,3,6trihydroxyanthraquinone, has been reported to be present in the fruit, which could account for the cancer chemopreventive activity exerted by noni (Pawlus et al. 2005).

Noni has been tested in various bioassays, in vitro and in vivo, to indicate the absence and/ or evaluate its genotoxic potential, including gene mutation (HPRT), unscheduled DNA synthesis (UDS), Comet assay, Ames test (Westendorf et al. 2007), micronucleus in mouse, chromosomal aberration in human lymphocytes (Edwards 2002, 2003) and somatic mutation and homologous recombination in Drosophila melanogaster (Franchi et al. 2008).

The purpose of this study was to directly evaluate antimutagenic and/or antirecombinagenic effects of TNJ using the Somatic Mutation and Recombination Test (SMART). This assay is based on the loss of heterozigosity ( $\mathrm{LOH})$ induction that may occur through various mechanisms, such as point and chromosomal mutations, as well as mitotic recombination. This versatile short-term in vivo assay detects simultaneously mutational and mitotic recombination, being able to quantify the recombinagenic activity of a compound in a genotoxicity screening (Franchi et al. 2009, Téllez et al. 2007, Toledo et al. 2008).

\section{MATERIALS AND METHODS}

\section{CHEMicAl COMPOUNDS}

In this study we used a commercial noni fruit juice produced by Morinda Inc (Tahitian Noni ${ }^{\circledR}$ Juice manufactured by Tahitian Noni International Inc. 333 West River Park Drive Provo, UT 84604, USA; and imported by Morinda International Brazil Ltda. - São Paulo - Brazil), that was introduced in the global market in 1996 and became commercialized 
in Brazil in 2002. Mitomycin C $\left(\right.$ Mitocin $^{\circledR}-$ MMC - CAS N. 50-07-7, manufactured by Kyowa Hakko Kirin Co. Ltd. and imported by Bristol-Myers Squibb Farmacêutica S.A. - Santo Amaro - SP - Brazil) and doxorubicin (Oncodox ${ }^{\circledR}$ - DXR - CAS N. 2321492-8 manufactured by Cipla Ltd. - Goa - India and imported by Meizler Biopharma S.A.) were used as positive controls. The compounds were dissolved in distilled water immediately before use, and the solvent was used as negative control.

THE SOMATIC Mutation AND RECOMBINATION TEST (SMART)

The wing SMART is based on the identification of wing hairs with mutant phenotypes that represent the occurrence of injuries at DNA level. Such alterations are primordially induced in cells of the imaginal discs, which mitotically divide to originate the adults' wings. Thereby, to obtain more detailed data about the antigenotoxic profile of TNJ, we employed the standard version of the wing SMART in Drosophila melanogaster (Andrade et al. 2003, Graf et al. 1984).

\section{FLY STOCKS}

The following stocks of $D$. melanogaster, with genetic markers on the left arm of chromosome 3, were used: (i) $m w h / m w h$, carrying the wing cell marker 'multiple wing hairs' (mwh abbreviated) and (ii) $f r^{3} / \operatorname{In}(3 \mathrm{LR}) \mathrm{TM} 3$, ri $p^{p}$ sep bx $x^{34 e}$ es $B d^{S}$ ( $f r^{3}$ abbreviated).

The wing cell marker 'flare' $\left(f t r^{3}\right)$ is a zygotic recessive lethal gene, which is maintained in the strain over the balancer chromosome TM3.

\section{STANDARD (ST) CROSSING}

The crossings were carried out en masse for 3 days, in glass vials containing standard culture medium, using $80 \mathrm{flr}^{3}$ virgin females and $30 \mathrm{mwh}$ males (Graf and van Schaik 1992). The following progeny was produced from this cross: marker-heterozygous flies $\left(m w h+/+f l r^{3}\right)$ with phenotypically wild-type wings; and balancer-heterozygous flies ( $m w h+/+$ TM3, $B d^{S}$ ) with phenotypically serrate wings.

\section{TREATMENTS}

Eggs derived from ST crossing were collected for $8 \mathrm{~h}$ on standard medium enriched with baker's yeast supplemented with sucrose. After $72 \pm 4 \mathrm{~h}$, third-instar larvae were collected by flotation in running water and placed in bottles containing $0.9 \mathrm{~g}$ of Drosophila instant medium (Carolina Biological Supply Company, Burlington, NC, USA) rehydrated with $3 \mathrm{~mL}$ of the treatment solutions. The co-treatment was carried out by mixing the mutagens, MMC (0.05 mM) or DXR $(0.2 \mathrm{mM})$, with three concentrations of TNJ $(25 \%, 50 \%$, and $75 \% \mathrm{v} / \mathrm{v}$ ). Larvae were fed on instant medium until pupation (about $48 \mathrm{~h}$ ). After emergence, adult flies were collected from the treatment vials and stored in $70 \%$ ethanol. Their wings were mounted in Faure's solution on slides and wing hair mutations were analyzed under a $400 \times$ magnification.

SCORING OF WINGS

The induction of $\mathrm{LOH}$ in the marker-heterozygous flies produce two mutant clones types: (i) single spots, either $m w h$ or $\mathrm{fl}^{3}$, resulting from point or chromosome mutations as well as mitotic recombination, and (ii) twin spots, consisting of both $\mathrm{mwh}$ and $\mathrm{fl}^{3}$ subclones, originating exclusively from mitotic recombination (Graf et al. 1984). In the balancer-heterozygous genotype, $m w h$ spots reflect predominantly somatic point mutation and chromosome mutation, since mitotic recombination involving the balancer chromosome and its structurally normal homologue is a lethal event (Vogel et al. 1999).

\section{DATA COLLECTION AND STATISTICAL ANALYSIS}

Two complete independent experimental procedures were performed. As the data of each individual 
experiment were not heterogeneous ( $p$ clearly < 0.05 in the Kruskall-Wallis Test), all data were pooled for statistical testing. The adults from each experimental group were collected and both flies' wings were mounted on slides. Both dorsal and ventral sides of the wings were analyzed; altogether approximately 48,800 cells were examined per fly.

The relative frequencies of each type of mutant clone per fly in a treatment series were compared pair-wise (i.e., genotoxin versus genotoxin $+\mathrm{TNJ}$ ) using the conditional binomial test according to Kastenbaum and Bowman (1970). The data was evaluated according to the multiple decision procedure proposed by Frei and Würgler (1988, 1995) resulting in four possible diagnostic: positive, negative, inconclusive or weak positive antigenotoxicity.

\section{RESULTS}

Prior to the antigenotoxicity assessment, TNJ was submitted to a dose range test, demonstrating that concentrations from 25 to $100 \% \mathrm{v} / \mathrm{v}$ do not exert toxic effects (Franchi et al. 2008). The concentrations used to assess TNJ antigenotoxic effects ranged from 25 to $75 \% \mathrm{v} / \mathrm{v}$ and were coadministered with $0.05 \mathrm{mM}$ of MMC or $0.2 \mathrm{mM}$ of DXR. These concentrations induce genotoxic effects without affecting fly survival, as also observed in previously published results (Rezende et al. 2011, Santos 1999).

The antigenotoxic effects of TNJ, measured by the wing SMART, after chronic co-exposure to MMC and DXR are summarized in Table I. TNJ showed a statistically significant $(p<0.05)$ inhibitory effect against MMC and DXR in the frequencies of total spots for both genotypes ( $m w h / f r^{3}$ and mwh/ $\mathrm{TM} 3, B d^{S}$ ), although only a weak positive effect was observed in flies treated with the lowest dose of TNJ + MMC.

For the $m w h / f l r^{3}$ flies, the total spot frequency was reduced by 41,68 and $85 \%$ in MMC cotreatments, and 66, 79 and $90 \%$ in DXR co- treatment, for concentrations of 25,50 and $75 \%$ of TNJ, respectively. TNJ also had a significant $(\mathrm{p}<0.05)$ positive antimutagenic action against MMC and DXR in the $m w h / \mathrm{TM} 3, B d^{S}$ flies, considering the total spot category. Mutant clones induced by recombination are not recovered in the balancer-heterozygous flies, indicating that the spots detected in this genotype are all of mutational origin (point and/or chromosomal). The inhibition observed was of 63,71 and $97 \%$ for MMC-treated flies; and of 83, 92 and $96 \%$ for DXR-treated flies, for concentrations of 25,50 and $75 \%$ of TNJ, respectively.

The effect on mutation and recombination induced by both genotoxins, and its modulation by TNJ is shown in Figure 1. MMC $(0.05 \mathrm{mM})$ induced a total of 24.17 spots per fly through a combination of mutation and recombination, while 25,50 and $75 \%$ concentrations of TNJ decreased this frequency to $14.60,8.25$ and 4.40 , respectively. MMC alone induced 5.31 spots per fly due exclusively to mutation, and 18.86 due to mitotic recombination. TNJ administered in the culture media reduced the MMC mutational frequency to $2.27,1.86$ and 0.60 , while the MMCrecombinational frequency was decreased to 12.33 , 6.39 and 3.80 respectively, demonstrating a doseresponse effect for both MMC-genotoxic events.

DXR $(0.2 \mathrm{mM})$ induced a total frequency of 10.37 spots, but when TNJ $(25,50$ and $75 \%)$ were co-administered this frequency dropped to 3.80 , 2.43 and 1.35 (Table I). DXR induced 0.85 spots per fly due exclusively to mutation and all TNJ concentrations reduced DXR mutation to a similar value of $\sim 0.30$ spots (Figure 1). We observed a clear dose response behavior to DXR recombinational frequency that changed from 9.49 to $3.41,2.10$ and 1.05, in TNJ concentrations of 25, 50 and $75 \%$, respectively. In terms of TNJ antigenotoxic potential these frequencies represent a drop of 56$66 \%$ and $63-87 \%$ in the frequency of mutation and recombination induced by DXR. 


\section{DISCUSSION}

In a previous report we have demonstrated that TNJ $(25,50,75$ and $100 \% \mathrm{v} / \mathrm{v})$ has no genetic toxicity effects in somatic cells of Drosophila melanogaster (Franchi et al. 2008), indicating the absence of TNJ mutational and recombinational actions. Previous studies have also shown that TNJ did not induce gene mutations at the HPRT locus (in 0.003 to 3 $\mu \mathrm{L} / \mathrm{mL}$ dose range), in presence and absence of S9 mix. In the same study, no mutagenic activity of ethyl-acetate extract from noni juice (100-fold concentrated) was observed in Chinese hamster V79-cell line (Westendorf et al. 2007). There was no increase in micronuclei nor any evidence of systemic toxicity in mice ascribed to dehydrated TNJ (10 g/kg body weight) when administered via oral gavage (Edwards 2002). Also, no significant increases were noted in the frequency of chromosome aberrations in cultured cells from human lymphocytes $(625,1250,2500$, and 5000 $\mu \mathrm{g} / \mathrm{mL}$ ) in presence or absence of S9 mix (Edwards 2003, Ratanavalachai et al. 2008, West et al. 2006).

Considering these findings, we decided to evaluate the antimutagenic and/or antirecombinagenic action of TNJ. In our study, the cotreatment with different concentrations of TNJ plus DXR or MMC induced a statistically significant dose-response reduction in the frequencies of spots in flies.

TABLE I

Effect of the co-treatment (TNJ + MMC and TNJ + DXR) in somatic cells of Drosophila melanogaster using the wing SMART standard cross.

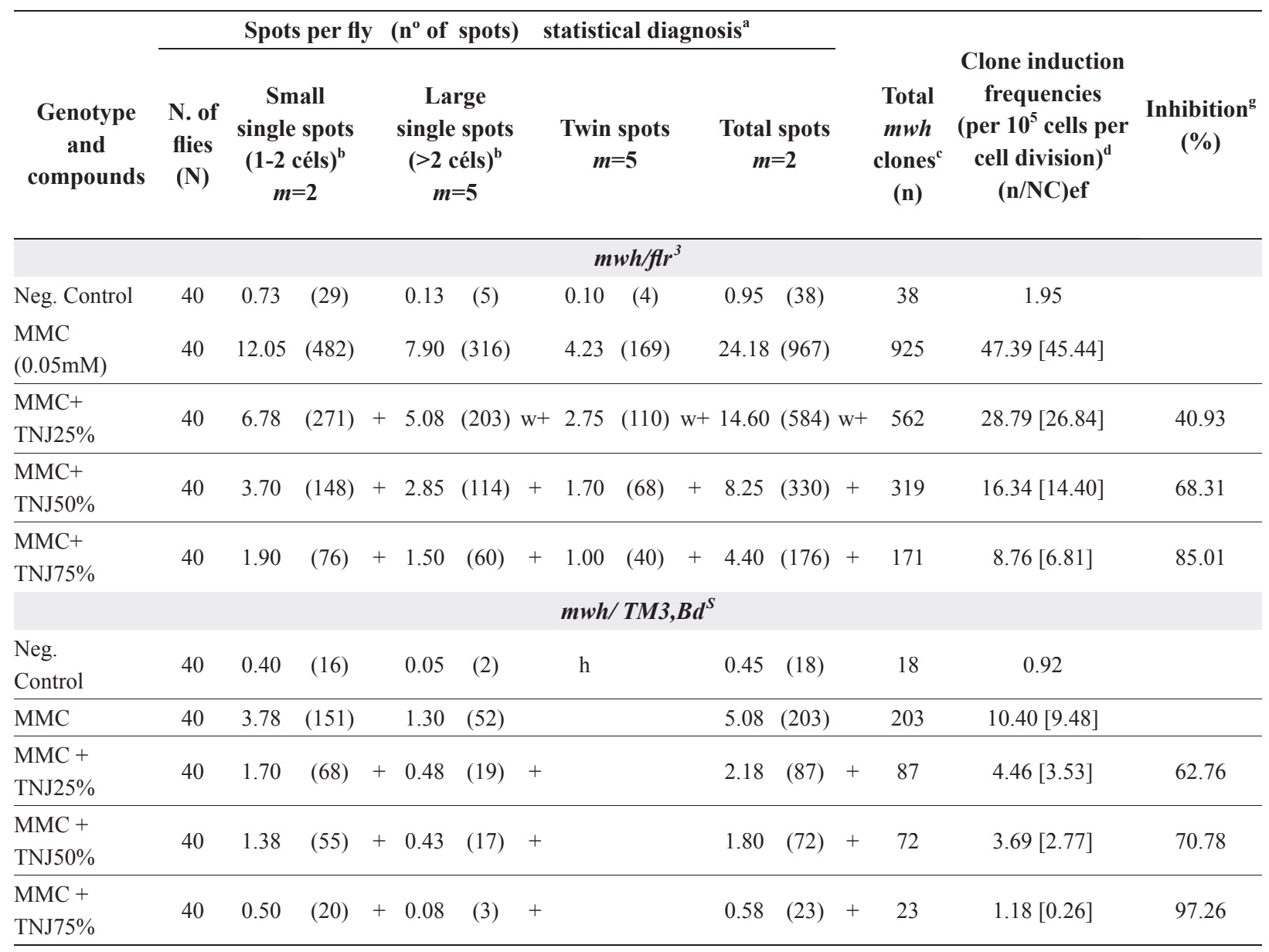


TABLE I (CONTINUATION)

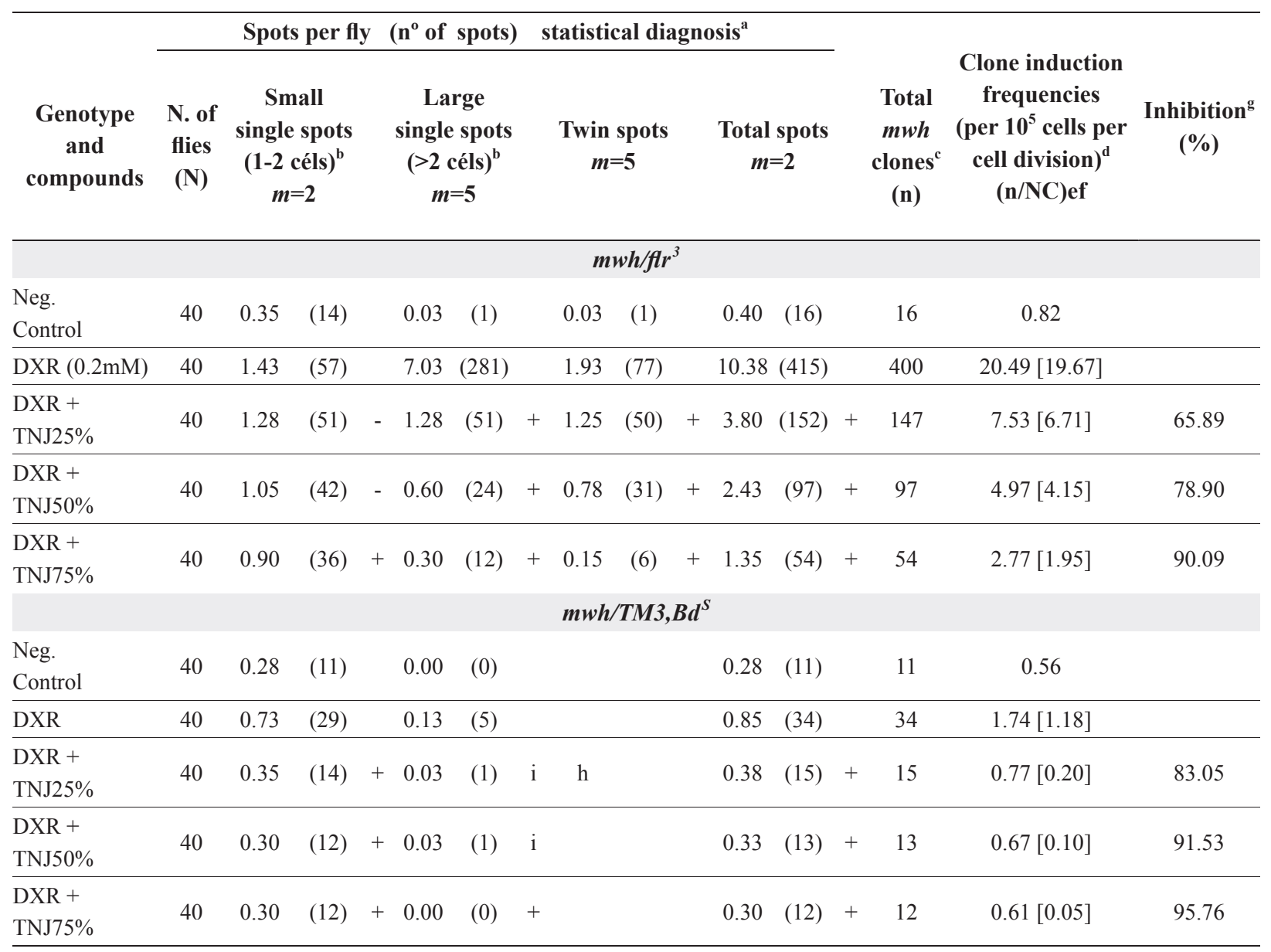

${ }^{\text {a }}$ Statistical diagnosis according to Frei and Würgler (1988): +, positive; -, negative; i, inconclusive. $m$, factor of multiplication for evaluation of results significantly negatives. Levels of significance $\alpha=0,05 .{ }^{\mathrm{b}}$ Including rare single spots $f r^{3}$. ${ }^{\mathrm{c}} \mathrm{Considering}$ clones $m w h$ for single spots $m w h$ and for twin spots. ${ }^{\mathrm{d} C}$ alculated accordance with Frei et al. $(1992) .{ }^{\mathrm{e}} \mathrm{C}=48,800$, i. e., approach number of cells examined for individual. ${ }^{\mathrm{f}}$ Numbers between keys are the corrected frequencies of induction in relation incidence estimate of the negative control. ${ }^{\mathrm{g}}$ Calculated according to Abraham (1994): (genotoxin alone-genotoxin plus TNJ/genotoxin alone) $\times 100$. h Just single spots $m w h$ can be observed in heterozygous individual $m w h / T M 3, B d^{5}$, since TM3 balancer chromosome does not contain the mutant gene $f r^{3}$.

DXR and MMC are two well known antineoplasic agents used in the treatment of solid tumors (Begleiter 2000, Minotti et al. 2004). DXR inhibits the activity of the enzyme topoisomerase II, inducing DNA strand breaks (Islaih et al. 2005, Resende et al. 2006), while MMC acts primarily by promoting DNA crosslinkage (Efimov and Fedyunin 2010, Riley and Workman 1992, Tomasz et al. 1987). Through these mechanisms, MMC and DXR are able to induce mutations and chromosomal aberrations in both tumor and nontumor cells. Moreover, cellular enzymes are capable of converting DXR and MMC into free radical metabolites (Benchekroun et al. 1993, Dusre et al. 1989, Menegola et al. 2001), which in turn induce damage to several molecules, such as DNA.

Many studies have suggested the coadministration of antineoplasic agents and free radical scavengers, such as antioxidants, to reduce the genotoxicity of such treatments in non-tumor 

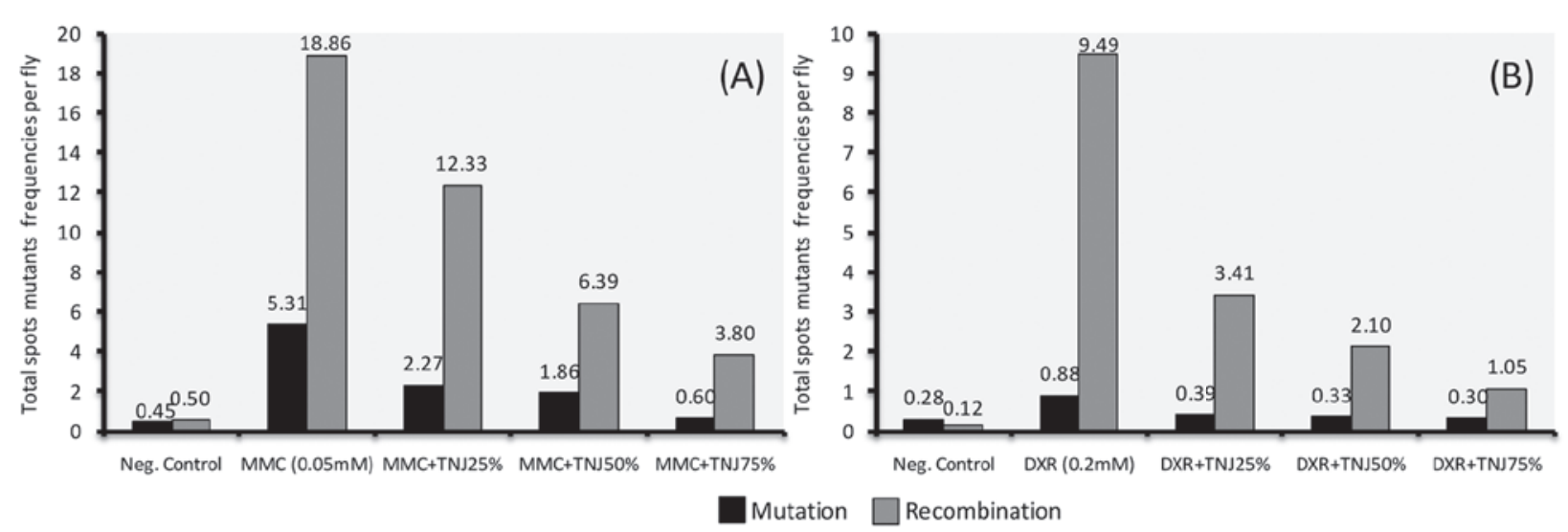

Figure 1 - Contribution of mutation and recombination to total mutant spots frequencies per fly in trans-heterozygous flies treated with MMC (A) or DXR (B) in combination with TNJ $(25 \%, 50 \%, 75 \%)$. The recombinagenic action was calculated according to Graf et al. (1992) and Sinigaglia et al. (2006) as follows: Frequencies $(F)=$ total $m w h$ clones (n) /number of flies (N); Mutation Frequencies $(F \mathrm{M})=$ frequencies of $m w h$ clones in balancer-heterozygous/frequencies of $m w h$ clones in marker trans-heterozygous; Recombination Frequencies $(F \mathrm{R})=1-F M$; Frequencies of Total Spots $(F \mathrm{~T})=$ total spots in $m w h / f l r^{3}$ flies $($ considering $m w h$ and $f l r^{3}$ spots $) /$ number of flies; Mutation $=F^{\prime} \mathrm{I} \times F \mathrm{M}$; Recombination $=F^{\prime} \mathrm{I} \times F \mathrm{~K}$.

cells (Amara-Mokrane et al. 1996, Antunes et al. 2007, Antunes and Takahashi 1998, Costa and Nepomuceno 2006, Fragiorge et al. 2007, Gentile et al. 1998, Tavares et al. 2006). So, the noni juice may be promising in this scenario.

In this study, TNJ produced a marked decrease in all kinds of MMC- and DXR-induced mutant spots. However, the largest effect observed in the co-administration of TNJ with MMC and DXR was antirecombinagenic, resulting in 82 and $87 \%$ reductions, respectively.

The mechanisms by which TNJ exerts its antigenotoxic activity are not clear at the present. However, antioxidant and/or free radical scavenger activities could be suggested. The radical scavenging activity has been measured in vitro using the terazolium nitroblue (TNB) assay, by assessing the juice's potential capacity to protect cells or lipids from oxidative alteration promoted by a superoxide anion radical (SAR). The SAR scavenging activity of TNJ was 2.8 times higher than that of vitamin $\mathrm{C}$, and 1.4 times higher than that of pycnogenol and grape seed powder (Wang and Su 2001). TNJ's protective effects were proportional to the concentrations applied, indicating a dose-response correlation.
Iridoids and potent antioxidant phenolic compounds, such as deacetylasperulosidic acid, scopoletin, isoscopoletin, aesculetin, 7-hydroxycoumarin (7$\mathrm{HC}$ ), quercetin, americanin A have been identified in noni fruits (Dussossoy et al. 2011, Ikeda et al. 2009, Liu et al. 2007, Su et al. 2005, West et al. 2011). These findings suggest that several compounds, in particular iridois and phenolic compounds, could contribute separately or synergistically to an antioxidative and antigenotoxic activity in TNJ.

Alternatively, the antigenotoxic activity detected for TNJ could be attributed to the presence of QR inducers. These compounds, such as 2-methoxy-1,3,6-trihydroxyanthraquinone (Pawlus et al. 2005), scopoletin and quercetin (Nitteranon et al. 2011), have been described in noni fruit. QR is a phase II metabolizing enzyme that is induced in conjunction with other protective phase II enzymes. This induction of phase II enzymes, such as QR, is considered as a cancer chemopreventive - since potential oxidative and electrophilic molecules can be more readily metabolized and excreted before its interaction with cellular macromolecules, such as DNA. QR is also responsible for maintaining the reduced states of antioxidants such as $\alpha$-tocopherol 
and coenzyme Q10. QR inducers are sometimes referred to as "indirect antioxidants", and this activity is considered protective at the initiation stage of carcinogenesis (Dinkova-Kostova and Talalay 2000, Kensler 1997).

This study has successfully used the SMART to demonstrate the protective effects of TNJ on the genotoxicity of DXR and MMC. We conclude that TNJ provides greater protection against these drugs, and that antirecombinagenic activity was the predominant effect. A dose-response relationship was also observed and might be attributed mainly to their powerful scavenger ability. Nevertheless, further experiments should be carried out to gain a better understanding of the mechanism of action of noni phytocompounds and to ensure their safe clinical use.

\section{RESUMO}

Noni, nome Havaiano da fruta de Morinda citrifolia L., é uma planta medicinal e tradicional da Polinésia amplamente usada para o tratamento de muitas doenças entre as quais artrite, diabetes, asma, hipertensão e câncer. Neste trabalho, um suco comercial de noni (TNJ) foi avaliado para suas atividades protetoras contras as lesões induzidas por mitomicina C (MMC) e doxorrubicina (DXR) usando o teste de mutação e recombinação somática em Drosophila melanogaster. Larvas de terceiro estágio, trans-heterozigotas para dois genes marcadores ( $m w h$ e $f r^{3}$ ), foram cotratadas com TNJ mais MMC ou DXR. Observamos uma redução dos efeitos genotóxicos de MMC e DXR pelo suco. TNJ induziu uma forte redução em todos os tipos de manchas mutantes induzidas por MMC e DXR principalmente devido a uma atividade antirecombinante. Os efeitos protetotes de TNJ foram dependentes da concentração, indicando uma correlação dose-resposta, os quais podem ser atribuídos a uma potente ação antioxidante e/ou habilidade de sequestrar radicais livres pelo TNJ.

Palavras-chave: antigenotoxicidade, doxorrubicina, mitomicina C, SMART, suco de noni.

\section{REFERENCES}

ABRAHAM SK. 1994. Antigenotoxicity of coffee in the Drosophila assay for somatic mutation and recombination. Mutagenesis 9: 383-386.

AMARA-MOKRANE YA, LEHUCHER-MICHEL MP, BALANSARD G, DUMÉNIL G AND BOTTA A. 1996. Protective effects of alpha-hederin, chlorophyllin and ascorbic acid towards the induction of micronuclei by doxorubicin in cultured human lymphocytes. Mutagenesis 11: 161-167.

ANDrade HHR, Reguly ML AND LEHMANN M. 2003. Wing Somatic Mutation and Recombination Test. In: HENDERSON DS (Ed), Drosophila Cytogenetics Protocols - Methods in Molecular Biology. Humana Press Inc., Totowa, p. 389-412.

ANTUNES LMG, BUENO RDE, DiAs FD AND BIANCHI MDP 2007. Acetylsalicylic acid exhibits anticlastogenic effects on cultured human lymphocytes exposed to doxorubicin. Mutat Res Genet Toxicol Environ Mutagen 626: 155-161.

ANTUNES LMG AND TAKAHASHI CS. 1998. Effects of high doses of vitamins $\mathrm{C}$ and $\mathrm{E}$ against doxorubicin-induced chromosomal damage in Wistar rat bone marrow cells. Mutat Res Genet Toxicol Environ Mutagen 419: 137-143.

BEGLEITER A. 2000. Clinical applications of quinonecontaining alkylating agents. Front Biosci 5: E153-E171.

BENCHEKROUN MN, SINHA BK AND ROBERT J. 1993. Doxorubicin-induced oxygen-free radical formation in sensitive and doxorubicin-resistant variants of rat glioblastoma cell-lines. FEBS Lett 322: 295-298.

CARdon D. 2003. Le Monde des Teintures Naturelles. Belin, Paris, France, 586 p.

Chan-Blanco Y, Vaillant F, Perez AM, Reynes M, BRILlouet JM AND BRAT P. 2006. The noni fruit (Morinda citrifolia L.): A review of agricultural research, nutritional and therapeutic properties. J Food Compos Anal 19: 645-654.

Costa WF And NePOMUCENO JC. 2006. Protective effects of a mixture of antioxidant vitamins and minerals on the genotoxicity of doxorubicin in somatic cells of Drosophila melanogaster. Environ Mol Mutagen 47: 18-24.

Deng Y, ChIN YW, ChaI H, KELlER WJ AND KInGHORN AD. 2007. Anthraquinones with quinone reductase-inducing activity and Benzophenones from Morinda citrifolia (Noni) roots. J Nat Prod 70: 2049-2052.

Dinkova-Kostova AT And TAlalay P. 2000. Persuasive evidence that quinone reductase type 1 (DT diaphorase) protects cells against the toxicity of electrophiles and reactive forms of oxygen. Free Radic Biol Med 29: 231-240.

Dusre L, Mimnaugh EG, Myers CE And Sinha BK. 1989 Potentiation of doxorubicin cytotoxicity by buthionine sulfoximine in multidrug-resistant human breast tumor cells. Cancer Res 49: 511-515.

Dussossoy E, Brat P, Bony E, Boudard F, POUCheret P, Mertz C, GiaImis J AND Michel A. 2011. Characterization, anti-oxidative and anti-inflammatory effects of Costa Rican noni juice (Morinda citrifolia L.). J Ethnopharmacol 133: 108-115. 
EARLE J. 2001. Plantas Medicinales en el Trópico Húmedo. San José, CR, Editorial Guayacán, 246 p.

EDWARDS CN. 2002. Tahitian Noni Juice-mouse micronucleus test. Test Report. Scantox Biologisk Laboratorium, Lille Skensved, DK (Lab no. 47053).

EDWARDS CN. 2003. In vitro mammalian chromosome aberration test performed with human lymphocytes. Test Report. Scantox Biologisk Laboratorium. Lille Skensved, DK (Lab no. 48877).

EFIMOV V AND FEDYUNIN S. 2010. Cross-linked nucleic acids: isolation, structure, and biological role. Biochemistry 75: 1606-1627.

Fragiorge EJ, Spanó MA ANd Antunes LMG. 2007. Modulatory effects of the antioxidant ascorbic acid on the direct genotoxicity of doxorubicin in somatic cells of Drosophila melanogaster. Genet Mol Biol 30: 449-455.

Franchi LP, GUIMARÃES NN, LEHMANN M, ANDRAdE HHR AND CUNHA KS. 2008. Ausência de efeito tóxicogenético de Morinda citrifolia (noni) em células somáticas de Drosophila melanogaster. Rev Elet Farm 5(3): 46-53.

FRANCHI LP, PENTIADO NHGR, SILVA RDN, GUIMARÃES NN, JESUINO RSA, DE ANDRADE HHR, LEHMANN M AND CUNHA KS. 2009. Mutagenic and recombinagenic effects of lamivudine and stavudine antiretrovirals in somatic cells of Drosophila melanogaster. Food and Chem Toxicol 47: 578-582.

FREI H AND WÜRGLER FE. 1988. Statistical-methods to decide whether mutagenicity test data from drosophila assays indicate a positive, negative, or inconclusive result. Mutat Res 203: 297-308.

FREI H AND WÜRGLER FE. 1995. Optimal experimental design and sample size for the statistical evaluation of data from somatic mutation and recombination tests (SMART) in Drosophila. Mutat Res 334: 247-258.

Furusawa E, Hirazumi A, Story S AND Jensen J. 2003. Antitumour potential of a polysaccharide-rich substance from the fruit juice of Morinda citrifolia (Noni) on sarcoma 180 ascites tumour in mice. Phytother Res 17: 1158-1164.

Gentile JM, RAHIMI S, ZWIESLER J, Gentile GJ AND FERGUSON LR. 1998. Effect of selected antimutagens on the genotoxicity of antitumor agents. Mutat Res Fundam Mol Mech Mutagen 402: 289-298.

GRAF U AND VANSCHAIK N. 1992. Improved high bioactivation cross for the wing somatic mutation and recombination test in Drosophila melanogaster. Mutat Res 271: 59-67.

Graf U, Wurgler FE, Katz AJ, Frei H, JuOn H, Hall CB AND KALE PG. 1984. Somatic mutation and recombination test in Drosophila melanogaster. Environ Mutagen 6: 153-188.

Harada S, Hamabi W, Kamiya K, Satake T, Yamamoto J AND TOKUYAMA S. 2009. Preventive effect of Morinda citrifolia fruit Juice on neuronal damage induced by focal ischemia. Biol Pharm Bull 32: 405-409.

HiRAZUMI A AND FURUSAWA E. 1999. An immunomodulatory polysaccharide-rich substance from the fruit juice of Morinda citrifolia (noni) with antitumour activity. Phytother Res 13: 380-387.
Hirazumi A, Furusawa E, ChOU SC AND HoKama Y. 1996. Immunomodulation contributes to the anticancer activity of Morinda citrifolia (noni) fruit juice. Western Pharmacology Society - Proceedings of the Thirty-Ninth Annual Meeting 39: 7-9.

IKEDA R, WADA M, NISHIGAKI T AND NAKASHIMA K. 2009. Quantification of coumarin derivatives in Noni (Morinda citrifolia) and their contribution of quenching effect on reactive oxygen species. Food Chem 113: 1169-1172.

ISLAIH M ET AL. 2005. Relationships between genomic, cell cycle, and mutagenic responses of TK6 cells exposed to DNA damaging chemicals. Mutat Res Fundam Mol Mech Mutagen 578: 100-116.

KASTENBAUM MA AND BOWMAN KO. 1970. Tables for determining the statistical significance of mutation frequencies. Mutat Res Fundam Mol Mech Mutagen 9: 527-549.

KENSLER TW. 1997. Chemoprevention by inducers of carcinogen detoxication enzymes. Environ Health Perspec 105: 965-970.

LiU CH, XUE YR, Ye YH, YUAN FF, LiU JY AND ShUANG JL. 2007. Extraction and characterization of antioxidant compositions from fermented fruit juice of Morinda citrifolia (noni). Agric Sci China 6: 1494-1501.

Menegola E, Broccia ML and Renzo FD. 2001. Teratogenic effects of doxorubicin in rats at midgestation and at term. Teratogen Carcinogen Mutagen 21: 283-293.

Minotti G, Menna P, Salvatorelli E, Cairo G AND GIANNI L. 2004. Anthracyclines: Molecular advances and pharmacologic developments in antitumor activity and cardiotoxicity. Pharmacol Rev 56: 185-229.

NELSON SC. 2006. Species profiles for Pacific Island agroforestry: Morinda citrifolia (noni). http://www. traditionaltree.org/

Nitteranon V, Zhang G, Darien BJ ANd Parkin K. 2011. Isolation and synergism of in vitro anti-inflammatory and quinone reductase $(\mathrm{QR})$ inducing agents from the fruits of Morinda citrifolia (noni). Food Res Int 44: 2271-2277.

OHSAWA Y AND OHBA S. 1993. Damnacanthal. Acta Crystallographica Section C-Crystal Structure Communications 49: 2149-2151.

Palu AK, Kim AH, West BJ, Deng S, Jensen J And White L. 2008. The effects of Morinda citrifolia L. (noni) on the immune system: Its molecular mechanisms of action. J Ethnopharmacol 115: 502-506.

PAWlus AD, Su BN, Keller WJ AND Kinghorn AD. 2005. An anthraquinone with potent quinone reductase-inducing activity and other constituents of the fruits of Morinda citrifolia (Noni). J Nat Prod 68: 1720-1722.

Potterat O AND HAMBURGer M. 2007. Morinda citrifolia (Noni) fruit - Phytochemistry, pharmacology, safety. Planta Med 73: 191-199.

RATANAVALACHAI T, THITIORUL S AND NANDHASRI P. 2008. In Vitro genotoxic and antigenotoxic studies of Thai Noni fruit juice by chromosomal aberration and sister chromatid exchange assays in human lymphocytes. Songklanakarin J Sci Technol 30(5): 583-589. 
Resende FA, Mattos de Andrade Barcala CA, Da Silva FARIA MC, KATO FH, CUNHA WR AND TAVARES DC. 2006. Antimutagenicity of ursolic acid and oleanolic acid against doxorubicin-induced clastogenesis in $\mathrm{Balb} / \mathrm{c}$ mice. Life Sci 79: 1268-1273.

REZENDE AAA ET AL. 2011. The effect of the dibenzylbutyrolactolic lignan (-)-cubebin on doxorubicin mutagenicity and recombinogenicity in wing somatic cells of Drosophila melanogaster. Food Chem Toxicol 49(6): 1235-1241.

RILEY RJ AND WORKMAN P. 1992. DT-diaphorase and cancerchemotherapy. Biochem Pharmacol 43: 1657-1669.

SALUdES JP, GARSON MJ, FranzBLAU SG AND AgUinALdo AM. 2002. Antitubercular constituents from the hexane fraction of Morinda citrifolia Linn. (Rubiaceae). Phytother Res 16: 683-685.

SANTOS JH, GRAF U, REgUly ML AND ANDRADE HHR 1999. The synergistic effects of vanillin on recombination predominate over its antimutagenic action in relation to MMC-induced lesions in somatic cells of Drosophila melanogaster. Mutat Res Gen Toxicol Environ Mutagen 444(2): 355-365.

Sinigaglia M, LEHMANN M, BAUMgardt P, AMARAL VS, DiHL RR, REGULY ML AND ANDRADE HHR. 2006. Vanillin as a modulator agent in SMART test: Inhibition in the steps that precede N-methyl-N-nitrosourea-, N-ethyl-Nnitrosourea-, ethylmethanesulphonate- and bleomycingenotoxicity. Mutat Res 607: 225-230.

Su BN, Pawlus AD, Jung HA, Keller WJ, Mclaughlin JL AND KINGHORN AD. 2005. Chemical constituents of the fruits of Morinda citrifolia (Noni) and their antioxidant activity. J Nat Prod 68: 592-595.

TAVARES DC, BARCElos GRM, SILVA LF, TONIN CCC AND BASTOS JK. 2006. Propolis-induced genotoxicity and antigenotoxicity in Chinese hamster ovary cells. Toxicol in Vitro 20: 1154-1158.

TÉllez MGO, Rodríguez HB, Olivares GQ, SORTIBrÁN ANC, Cetto AA AND Rodríguez-Arnaiz R. 2007. A phytotherapeutic extract of Equisetum myriochaetum is not genotoxic either in the in vivo wing somatic test of Drosophila or in the in vitro human micronucleus test. J Ethnopharmacol 111: 182-189.
TOledo VM, TÉllez MGO, Sortibrán ANC, ANDradeCETTO A AND RoDRÍGUEZ-ARNAIZ R. 2008. Genotoxicity testing of Cecropia obtusifolia extracts in two in vivo assays: The wing somatic mutation and recombination test of Drosophila and the human cytokinesis-block micronucleus test. J Ethnopharmacol 116: 58-63.

TOMASZ M, LIPMAN R, CHOWDARY D, PAWLAK J, VERDINE GL AND NAKANISHI K. 1987. Isolation and structure of a covalent cross-link adduct between mitomycin-c and DNA. Science 235: 1204-1208.

Vogel EW, Graf U, Frei HJ AND Nivard MMJ. 1999. The results of assays in Drosophila as indicators of exposure to carcinogens. In: MCGREGOR DB, RICE JM AND VENITT S (Eds), Use of short- and medium-term tests for carcinogens and data on genetic effects in carcinogenic hazard evaluation. IARC Sci Publ 146: 427-470.

WANG MY AND SU C. 2001. Cancer preventive effect of Morinda citrifolia (Noni). Canc Prev 952: 161-168.

WAng MY, West BJ, Jensen CJ, Nowicki D, Su C, PALU AK AND ANDERSON G. 2002. Morinda citrifolia (Noni): A literature review and recent advances in Noni research. Acta Pharmacol Sin 23: 1127-1141.

West BJ, Deng S And Jensen CJ. 2011. Nutrient and phytochemical analyses of processed noni puree. Food Res Int 44: 2295-2301.

West BJ, Jensen CJ, Westendorf J And White LD. 2006 A safety review of Noni fruit juice. J Food Sci 71: R100-R106.

WESTENDORF J, EFFENBERGER K, IZNAGUEN H AND BASAR S. 2007. Toxicological and analytical investigations of noni (Morinda citrifolia) fruit juice. J Agric Food Chem 55: 529-537.

Yu H, Li S, HuANG MT AND Ho CT. 2008. Antiinflammatory constituents in noni (Morinda citrifolia) fruits, Dietary Supplements. American Chemical Society, p. 179-190. 